Archives de sciences sociales des religions

156 | octobre-décembre 2011

Bulletin Bibliographique

\title{
José María Blasquez,Cristianismo y mitos clásicos en el arte moderno
}

Madrid, Ediciones Cátedra, coll. « Historia. Serie Menor », 2009, 400 p.

Rodolfo de Roux

\section{OpenEdition}

\section{Journals}

Édition électronique

URL : http://journals.openedition.org/assr/23451

DOI : 10.4000/assr.23451

ISSN : $1777-5825$

Éditeur

Éditions de l'EHESS

Édition imprimée

Date de publication : 31 décembre 2011

Pagination : 118

ISBN : 9782713223273

ISSN : 0335-5985

\section{Référence électronique}

Rodolfo de Roux, "José María Blasquez,Cristianismo y mitos clásicos en el arte moderno », Archives

de sciences sociales des religions [En ligne], 156 | octobre-décembre 2011, document 156-21, mis en ligne le 14 février 2012, consulté le 21 septembre 2020. URL : http://journals.openedition.org/assr/ 23451 ; DOI : https://doi.org/10.4000/assr.23451

Ce document a été généré automatiquement le 21 septembre 2020

(C) Archives de sciences sociales des religions 


\title{
José María Blasquez,Cristianismo y mitos clásicos en el arte moderno
}

\author{
Madrid, Ediciones Cátedra, coll. « Historia. Serie Menor », 2009, 400 p.
}

\author{
Rodolfo de Roux
}

\section{RÉFÉRENCE}

José María BLASQUEZ, Cristianismo y mitos clásicos en el arte moderno, Madrid, Ediciones Cátedra, coll. « Historia. Serie Menor », 2009, 400 p.

1 El autor, catedrático emérito de Historia Antigua de la Universidad Complutense de Madrid y conocido especialista sobre las religiones mediterráneas e ibéricas del Mundo Antiguo, también se ha interesado por la pervivencia del cristianismo y de la mitología greco-romana en los grandes artistas del mundo moderno. El presente volumen, compuesto por 19 capítulos que pueden leerse independientemente los unos de los otros, recoge 18 artículos publicados entre 1972 y 2008 en diversas revistas españolas y extranjeras.

Dos terceras partes de la obra (o sea, 256 páginas) están consagradas a los mitos clásicos. En ellas se abordan los "Temas de la mitología clásica en las pinturas de la corte de Felipe II" (cap. I), los "Mitos clásicos en la Gemäldegalerie Alte Meister de Kassel" (cap. II), "El mito griego de Leda y el cisne en mosaicos hispanos del Bajo Imperio y en la pintura europea" (cap. III), los "Mitos clásicos en la pintura moderna" (cap. IV), los "Mitos griegos en la pintura expresionista" (cap. V), los "Temas del mundo clásico en las pinturas de Kokoschka y Braque" (cap. IX), "El mundo clásico en Picasso" (cap.XI), los "Temas del mundo clásico en el arte moderno español" (cap. XII), los "Temas del mundo clásico en el arte del siglo Xx" (cap. XIII), los "Mitos clásicos en los periódicos y revistas de Madrid a finales del siglo xx" (cap. XV), los "Mitos clásicos en los periódicos y revistas de Madrid a comienzos del tercer milenio. Representaciones en el teatro" (cap. XVI), los "Mitos clásicos y naturaleza en la pintura y dibujos de Carlos Franco" (cap. XVIII) y "El mundo clásico en Dalí” (cap. XIX). 
3 Las 122 páginas dedicadas a los temas cristianos en el arte moderno tratan sobre "Las tentaciones de San Antonio en el arte contemporáneo" (cap. VI), "El arte religioso de Emil Nolde" (cap. VII), "La pintura religiosa en los expresionistas alemanes” (cap. VIII), “Arte religioso español del siglo xx: Picasso, Gutiérrez Solana y Dalí" (cap. X), "La pintura religiosa de Gutiérrez Solana y la iconografía de la muerte en el arte contemporáneo" (cap.XIV), "Grandes artistas españoles de finales del segundo milenio y el arte religioso" (cap. XVII).

4 Con loable preocupación pedagógica, el autor explica someramente en distintos lugares del libro tanto el contenido de los mitos griegos como el de los temas cristianos a los que aluden los cuadros analizados. La avalancha de información que proporciona esta obra deja bien en claro lo que se proponía el autor: mostrar que el mundo clásico y el cristianismo son las dos grandes raíces de la cultura occidental. La notable erudición de la que hace gala J.M. Blázquez es sin duda útil, pero adquiere frecuentemente el aspecto de un inventario de autores y de obras, en particular en los capítulos de temática más general. La naturaleza misma de este libro - una yuxtaposición de artículos publicados a lo largo de 36 años - hace inevitable un cierto número de repeticiones. Los diferentes capítulos no tienen un orden cronológico o temático. La obra hubiera podido ganar fácilmente en coherencia si se hubieran reagrupado por una parte los capítulos que tratan sobre el mundo clásico $y$, por otra parte, los que tratan sobre el cristianismo en el arte moderno. 